\title{
Phenotypic Diversity in Pseudomonas syringae pv. tomato
}

\author{
By TIMOTHY P. DENNY \\ Department of Plant Pathology, University of Georgia, Athens, GA 30602, USA
}

(Received 4 November 1987; revised 25 February 1988)

\begin{abstract}
Twenty-nine strains of Pseudomonas syringae pv. tomato ( $P$. s. tomato) that represented the temporal and geographical diversity of this pathogen were tested for pathogenicity on tomato, carbohydrate utilization, bacteriophage sensitivity, fatty acid composition and plasmid profile. The extent of phenotypic diversity observed within P. s. tomato depended on the trait examined; the strains were similar in pathogenicity, carbohydrate utilization and fatty acid content, whereas greater diversity was found in bacteriophage sensitivity and the plasmid profiles. A classification scheme for $P$. s. tomato plasmids based on both size and DNA homology is proposed. The array of phenotypic traits clearly differentiated all the strains of $P$. $s$. tomato examined from six strains of $P$. syringae pv. syringae, with carbohydrate utilization and fatty acid analyses being the most reliable.
\end{abstract}

\section{INTRODUCTION}

Pseudomonas syringae pv. tomato (Okabe) Young, Dye \& Wilke ( $P$. s. tomato) and P. syringae pv. syringae van Hall ( $P$. s. syringae) are among the more important pathogenic fluorescent pseudomonads. The cause of bacterial speck of tomato, $P$. s. tomato is found in many parts of the world (Goode \& Sasser, 1980; Bradbury, 1986). The incidence of $P$. s. tomato can reach epidemic proportions in fruit production fields (Kim, 1979; Smitley \& McCarter, 1982), causing reductions in both fruit quality and yield (Yunis et al., 1980; Smitley \& McCarter, 1982; Getz et al., 1983). Bacterial speck is of particular concern to producers of certified tomato seedling transplants in Georgia, since its discovery results in costly quarantines (Goode \& Sasser, 1980).

Tomato is the only common symptom host for P. s. tomato (Bradbury, 1986). In contrast, P. s. syringae has a broad host range, and some $P$. s. syringae strains cause lesions on tomato that appear very similar to those produced by $P$. s. tomato infection (Jones et al., 1981; Gitaitis et al., 1985). I wished to study the host selectivity of $P$. s. tomato, but was unable to pick a representative strain for genetic experiments because there was insufficient information on the diversity within this pathovar. There are studies where a limited number of strains of $P$. $s$. tomato have been tested for growth and/or fluorescence on selected carbohydrates (Sands $e t$ al., 1970; Jones et al., 1981, 1983b, 1986; Cuppels, 1983), serological reactivity (Fackrell \& Sinha, 1983; Jones et al., 1983a), bacteriophage sensitivity (Cuppels, 1983), toxin production (Mitchell et al., 1983) and other miscellaneous phenotypic traits (Sands et al., 1970). In these studies, however, strains either were not chosen to be representative of the pathovar, were tested only for a few phenotypic traits, or were not examined genetically. This situation is not unique to $P$. $s$. tomato, because researchers generally have emphasized the differences between $P$. syringae pathovars at the expense of studying the diversity within pathovars (Sands et al., 1970; Schroth et al., 1981).

The primary objective was to study the phenotypic and genetic diversity within $P$. s. tomato with a combination of conventional and new techniques. Strains were selected that were representative of the temporal and geographical diversity of $P$. s. tomato. Several strains of $P$. s. syringae were also examined to provide an indication of the differences between these pathovars. Traits examined included pathogenicity, carbohydrate utilization, bacteriophage 
sensitivity, fatty acid content and plasmid profile. Plasmid profiles were considered a phenotypic trait because only the plasmid responsible for copper resistance has an identifiable function (Bender \& Cooksey, 1987), and the stability of the plasmids was unknown.

\section{METHODS}

Bacterial strains and media. The strains of $P$. s. tomato and $P$. s. syringae used are described in Tables 1 and 2 , respectively. Strain AV80 was originally isolated by A. Vidaver, University of Nebraska, USA, and strain RG4 was isolated by J. M. Camino and W. Hidalgo, Posgrado en Fitopathologia, Universidad Centro Occidental 'Lisandro Alvarado', Barquisimeto, Venezuela. Each strain was purified by single-colony transfer and stored at $-80^{\circ} \mathrm{C}$ in $15 \%(\mathrm{v} / \mathrm{v})$ glycerol (Silhavy et al., 1984). Bacteria were grown on medium B of King et al. (1954), in Luria broth (LB) (tryptone, $10 \mathrm{~g}$; yeast extract, $5 \mathrm{~g} ; \mathrm{NaCl}, 5 \mathrm{~g}$; water, 1 l), or nutrient broth-yeast extract agar (Cuppels, 1983). The ability to utilize sucrose, $\mathrm{D}(-)$-tartrate, DL-lactate or erythritol as sole carbon sources was tested on the media described by Jones et al. (1981).

Pathogenicity tests. Pathogenicity on tomato (Lycopersicon esculentum Mill. 'Chico III') was tested by modifying the method of Cuppels (1986). Four seedlings were grown in pots of artificial soil, and the first true leaves were gently swabbed with bacterial suspensions (approximately $5 \times 10^{6}$ c.f.u. $\mathrm{ml}^{-1}$ ). The pots were immediately enclosed in clear polyethylene bags and placed in a growth chamber at $18-20^{\circ} \mathrm{C}$. The bags were removed after $36 \mathrm{~h}$ and symptoms recorded $7 \mathrm{~d}$ after inoculation. A similar method was used to test pathogenicity on cowpea [Vigna ungiculata (L.) Walp. subsp. ungiculata 'California Blackeye 3'], except that leaves were first dusted with carborundum (Jones et al., 1981).

Phage sensitivity. Bacteriophages PT1, PT18 and PT20 were provided by D. Cuppels (Agriculture Canada, London, Ontario, Canada). Phage sensitivity was determined according to Cuppels (1983), except that each phage was tested at three dilutions. These dilutions had titres of approximately $1 \times 10^{4}, 1 \times 10^{5}$, and $1 \times 10^{6}$ p.f.u. $\mathrm{ml}^{-1}$ when tested on strain Pst6, the designated indicator strain. The lowest dilution gave individual plaques when $10 \mu 1$ spots were applied to bacterial lawns growing in soft agar.

Fatty acid analysis. Cultures were grown for $36-48 \mathrm{~h}$ on nutrient agar (Difco) medium at $30^{\circ} \mathrm{C}$. Fatty acids were extracted from cells by the method described by Gitaitis et al. (1987) and analysed by gas-liquid chromatography. Samples ( $1 \mu \mathrm{l}$, splitless injection) were applied to a $30 \mathrm{~m}, 0.25 \mathrm{~mm}$ inner diameter, fused silica capillary column coated with a $25 \mu \mathrm{m}$ film of methylphenyl silicone (model DB-5, J \& W Scientific). The injector was at $250^{\circ} \mathrm{C}$, the flame ionization detector at $300^{\circ} \mathrm{C}$, and the column temperature programmed to increase from 145 to $280^{\circ} \mathrm{C}$ at $4{ }^{\circ} \mathrm{C} \mathrm{min}-1$. The linear velocity of the helium carrier gas was $23 \mathrm{~cm} \mathrm{sec}^{-1}$. The fatty acids in the samples were identified by comparing their retention times to those in a standard solution [Bacterial acid methyl esters mix, $\mathbf{C P}$ (\# 4-7080); Supelco]. Peak retention times, peak identification, peak area, and the relative percentage of fatty acids present were calculated with the aid of a Hewlett Packard 3350A Laboratory Automation System.

Plasmid DNA isolation and electrophoresis. Plasmid DNA was prepared by a modified alkaline lysis technique (Birnboim, 1983). Cells from an overnight culture $(8 \mathrm{ml})$ were suspended in $1.0 \mathrm{ml} 2 \times$ lysozyme buffer, followed by the addition of $25 \mu \mathrm{l} 5 \mathrm{mg}$ lysozyme $\mathrm{ml}^{-1}$ and then $1.0 \mathrm{ml}$ sterile, deionized water. After $5 \mathrm{~min}$ on ice, alkaline-SDS $(0.2 \mathrm{M}-\mathrm{NaOH}, 1 \%, \mathrm{w} / \mathrm{v}, \mathrm{SDS})$ and high salt solution ( $3 \mathrm{M}$-potassium acetate, $1.8 \mathrm{M}$-formic acid) were used as described for a large scale preparation, and the resulting precipitate was removed by centrifugation at $13800 \mathrm{~g}$ for $30 \mathrm{~min}$. The DNA in $8 \mathrm{ml}$ of the supernatant was precipitated by adding $5.0 \mathrm{ml}$ propan-2-ol and incubating at $20^{\circ} \mathrm{C}$ for $30 \mathrm{~min}$. The DNA was sedimented as above, washed with $70 \%(\mathrm{v} / \mathrm{v})$ ethanol and dissolved in $0 \cdot 1 \mathrm{ml}$ TE (10 mM-Tris/HCl, pH 8, 1.0 mM-EDTA). To remove contaminating linear DNA and polysaccharides the procedure was repeated using modified mini-prep conditions. The $0 \cdot 1 \mathrm{ml}$ solution was first diluted with $0 \cdot 1 \mathrm{ml} 2 \times$ lysozyme buffer and insoluble material was sedimented for $10 \mathrm{~min}$ in a microcentrifuge at $4{ }^{\circ} \mathrm{C}$. The supernatant was recovered and treated with alkaline-SDS and high salt solutions, and the precipitate was sedimented in a microcentrifuge. The plasmid DNA in $0.8 \mathrm{ml}$ of the supernatant was recovered, dissolved in $0.1 \mathrm{ml} \mathrm{TE}$, and stored at $4{ }^{\circ} \mathrm{C}$. Plasmid DNA used for restriction endonuclease digestion was treated with RNAase A $\left(80 \mu \mathrm{g} \mathrm{ml}^{-1} \mathrm{final}\right.$ concentration, $15 \mathrm{~min}$, room temperature), then with proteinase $\mathrm{K}\left(0.2 \mathrm{mg} \mathrm{ml}^{-1}\right.$ proteinase $\mathrm{K}, 0.1 \%$ SDS final concentrations, $\left.30 \mathrm{~min}, 50^{\circ} \mathrm{C}\right)$, extracted twice with phenol/chloroform $(1: 1, \mathrm{w} / \mathrm{v})$, once with chloroform, ethanol precipitated, and dissolved in $0.1 \mathrm{ml} \mathrm{TE}$.

Plasmid DNA was electrophoresed at $200 \mathrm{~V}\left(8.5 \mathrm{~V} \mathrm{~cm}^{-1}\right)$ for $6 \mathrm{~h}$ on $0.7 \%(\mathrm{w} / \mathrm{v})$ agarose gels maintained at $10^{\circ} \mathrm{C}$ by a cooling stage. The gels were stained with ethidium bromide and photographed with UV light $(300 \mathrm{~nm})$. When single plasmids were to be isolated for use as hybridization probes, gels were cast using low-melting temperature agarose (Seaplaque agarose; FMC).

DNA blotting and hybridization. Plasmid DNA was denatured and transferred from the agarose gels to nitrocellulose membranes (Smith \& Summers, 1980). Plasmids used as hydridization probes were isolated from Seaplaque agarose to remove contaminating linear DNA. Selected $P$. s. tomato plasmids (in 25-50 $\mu$ l agarose) were heated to $65^{\circ} \mathrm{C}$, applied to $0.025 \mu \mathrm{m}$ VS filters (Millipore), and dialysed against TE buffer for $2 \mathrm{~h}$ at room 
Table 1. Pseudomonas syringae pv. tomato strains

\begin{tabular}{llll} 
& \multicolumn{2}{c}{ Isolation } & \\
10862 & Location & Date & Source \\
NCPPB 880 & Canada & 1941 & ATCC \\
NCPPB 2424 & Yugoslavia & 1953 & DC \\
CNBP 1323 & Switzerland & 1969 & DC \\
PDDCC 3357 & France & 1971 & DC \\
31861 & New Zealand & 1972 & DC \\
B118 $\ddagger$ & Australia & 1975 & PF \\
B88, B117 & Florida, USA & 1978 & SM \\
30555 & Georgia, USA & 1978 & SM \\
B19, B122 & Tasmania, Australia & 1978 & PF \\
B121 & California, USA & 1979 & SM \\
B120 $\ddagger$ & New Jersey, USA & 1979 & SM \\
AV80 & Delaware, USA & 1980 & SM \\
B125 & Nebraska, USA & 1980 & DC \\
T4B1 & Canada & 1981 & SM \\
B181, B191 & Canada & 1981 & DC \\
PT14 & Georgia, USA & 1981 & SM \\
PT21 & California, USA & 1982 & CB \\
JL1031, JL1053, JL1060, & California, USA & 1983 & CB \\
JL1075, JL1105, JL1120 & California, USA & 1983 & JL \\
RG4 & Venezuela & 1985 & SM \\
PT30 & California, USA & 1985 & CB \\
\hline
\end{tabular}

* Strain numbers used are those of the researchers who supplied the cultures. Abbreviations are: CNBP, Collection National de Bactéries Phytopathogènes, Angers, France; NCPPB, National Collection of Plant Pathogenic Bacteria, Harpenden, UK; PDDCC, Plant Diseases Division Culture Collection, Auckland, NZ. $\dagger$ Abbreviations are: ATCC, American Type Culture Collection; CB, C. Bender, Oklahoma State, University, USA; DC, D. A. Cuppels, Agriculture Canada, Ontario, Canada; JL, J. Lindeman, Advanced Genetic Sciences, Oakland, California, USA; PF, P. Fahy, Department of Agriculture, New South Wales, Australia; SM, S. McCarter, University of Georgia, USA.

$\ddagger$ Original strain numbers and source (given in parentheses) are as follows: B118 was 78-2 (R. Stall, University of Florida, USA); B19 was 14D46 (C. Kado, University of California, Davis, USA); B122 was DS389 (J. Watterson, Petoseed Co., Woodland, Cali., USA); B121 was PT51 (D. Coplin, Ohio State University, Wooster, USA); B120 was 44(997) (M. Sasser, University of Delaware, USA).

Table 2. Pseudomonas syringae pv. syringae strains

\begin{tabular}{lllcl} 
& \multicolumn{3}{c}{} & \\
Strain* & $\overbrace{\text { Host }}^{\text {Isolation }}$ & Location & Date & \multicolumn{1}{c}{ Original designation and source } \\
B48 & Peach & S. Carolina & 1972 & B-3, W. M. Dowler, Clemson University, USA \\
B61 & Wheat & S. Dakota & ND & 240, J. D. Otta, South Dakota State University, USA \\
B64 & Wheat & Minnesota & ND & \# I, R. D. Wilcoxson, University of Minnesota, USA \\
B76 & Tomato & Georgia & 1980 & PT-80-12 \\
B78 & Tomato & Georgia & 1980 & PT-80-1 $\}$ R. D. Gitaitis, University of Georgia, USA \\
PSC1B & Corn & Nebraska & ND & A. Vidaver, University of Nebraska, USA
\end{tabular}

ND, No data.

* Strain PSC1B was provided by D. Cuppels. All other strains were provided by S. McCarter.

† Present addresses: W. M. Dowler, USDA Plant Disease Laboratory, Fort Detrick, Md., USA; J. D. Otta, Rhone Poulenac Inc., Volga, S. Dak., USA.

temperature (Silhavy et al., 1984). The solidified agarose containing the plasmid DNA was recovered, melted, and added immediately to a nick-translation reaction mixture $(200 \mu \mathrm{l}$ final volume $)$ to incorporate $\left[{ }^{32} \mathrm{P}\right] \mathrm{dATP}$ (Maniatis et al., 1982). Labelled DNA was isolated, heat denatured along with salmon testes DNA, mixed with the hydridization solution [ $50 \%, \mathrm{v} / \mathrm{v}$, deionized formamide; $10 \%, \mathrm{w} / \mathrm{v}$, dextran sulphate; $1 \times$ Denhardt's solution; $5 \times$ SSC $(1 \times \mathrm{SSC}$ is $0.15 \mathrm{M}-\mathrm{NaCl}, 0 \cdot 015 \mathrm{M}$-sodium citrate, $\mathrm{pH} 7)]$ (Wahl et al., 1979), and then added to a plastic bag 
containing a membrane pre-wetted in $4 \times$ SSC plus $1 \times$ Denhardt's solution. After hybridization overnight at $42{ }^{\circ} \mathrm{C}$, membranes were washed for $15 \mathrm{~min}$ twice at room temperature in $2 \times$ SSC plus $0.1 \% \mathrm{SDS}$, then for $15 \mathrm{~min}$ five times at $52-55{ }^{\circ} \mathrm{C}$ in $0.1 \times$ SSC plus $0.1 \%$ SDS, air dried, and autoradiographed using X-ray film (XAR-5, Kodak) and an intensifying screen (Cronex Lightning Plus; DuPont). Filters to be reused were washed for $20 \mathrm{~min}$ three times in $0.1 \% \mathrm{SDS}, 2.0 \mathrm{~mm}$-EDTA at $65^{\circ} \mathrm{C}$, which removed most, but not all of the labelled DNA probe.

\section{RESULTS}

\section{Pathogenicity}

All strains of $P$. s. tomato except 10862 were pathogenic on unwounded tomato seedlings, producing typical lesions with variable haloes. None of the $P$. s. syringae strains was pathogenic under the same conditions. When tomato leaves were wounded with carborundum during inoculation, $P$. s. syringae strains B76 and B78 caused small lesions similar to those of $P$. $s$. tomato, but $P$. s. tomato strain 10862 was still non-pathogenic. All the $P$ s. syringae strains were pathogenic on cowpea when tested on carborundum-injured leaves.

\section{Carbohydrate utilization}

All $P$. s. tomato and $P$. s. syringae strains grew on sucrose as a sole carbon source. All strains of $P$. s. tomato except 10862 grew on $\mathrm{D}(-)$-tartrate and none utilized DL-lactate or erythritol. $P$. $s$. syringae strains grew on media with DL-lactate and erythritol but not on $\mathrm{D}(-)$-tartrate, except for strain B78, which grew on all the carbohydrates tested.

\section{Bacteriophage sensitivity}

The $P$. s. tomato and $P$. s. syringae strains were tested for their sensitivity to all three bacteriophages, but phages PT1 and PT18 gave identical results so only the data from PT1 and PT20 infection are shown (Table 3). The majority of $P$. s. tomato strains were positive (sensitive) for both PT1 and PT20, giving phage titres similar to the Pst6 test strain. Some strains, however, were variable in their response to PT20. The development of plaques by these variable strains appeared to depend on the number of bacteria used to form the indicator lawn; too many cells obscured the formation of the turbid plaques. The remaining strains were positive for PT1 and negative for PT20, but strains B118, B191, PT14 and PT21 were unusual in that 10- to 100-fold fewer plaques than expected were formed. The simplest explanation for this apparent reduction in phage titre is that fewer cells of these strains allowed phage infection or multiplication. In contrast to $P$. s. tomato, most of the $P$. s. syringae strains were completely negative for PT1 (Table 3).

Table 3. Phage typing of $P$. syringae pv. tomato and $P$. syringae pv. syringae

\section{Strain}

$P$. syringae pv. tomato

B88, B117, B121, B122, B125, T4B1, AV80, JL1105,

JL1120, RG4, CNBP 1323, 30555, PDDCC 3357, PT30

B19, JL1060, JL1075, NCPPB 2424

B120, B181, JL1031, JL1053, NCPPB 880, 10862,

31861

B118, B191, PT14, PT21

P. syringae pv. syringae

B48, B61, B64

B76

PSC1B

B78

$\begin{array}{cl}\overbrace{\text { PT1 }}^{\text {Phage* }} & \text { PT20 } \\ & \\ ++ & ++ \\ ++ & \operatorname{var}(\mathrm{t}) \\ ++ & - \\ +(\mathrm{t}) & - \\ & \\ - & - \\ - & \operatorname{var}(\mathrm{t}) \\ ++ & ++(\mathrm{t}) \\ & \operatorname{var}(\mathrm{t})\end{array}$

* Phage sensitivity: ++ , titre comparable to test strain Pst6; + , titre 10- to 100-fold lower than when tested on Pst6; var, normal titre but variable occurrence; $t$, turbid plaques. Plaques were clear unless indicated otherwise. 
Table 4. Fatty acid analysis of selected P. syringae strains

The twelve $P$. s. tomato strains examined were B88, B118, T4B1, AV80, JL1120, RG4, NCPPB 2424, NCPPB 880, CNBP 1323, 10862, 31862 and PDDCC 3357. The four $P$. s. syringae strains were B48, B76, B78 and PSC1B. The fatty acids are listed in order of increasing retention time. Abbreviations are: $12: 0$, dodecanoic acid; 2-OH-12:0, 2-hydroxydodecanoic acid;3-OH-12:0, 3-hydroxydodecanoic acid; $14: 0$, tetradecanoic acid; $16: 1$, 9-hexadecenoic acid; $16: 0$, hexadecanoic acid; $\Delta 17: 0,9,10$ methylenehexadecanoic acid, $18: 1$, 9-octadecenoic acid.

\begin{tabular}{lccr} 
Fatty acid & \multicolumn{3}{c}{ pv. tomato $(n=12)$} \\
\cline { 2 - 4 } $12: 0$ & $2 \cdot 89-8 \cdot 72$ & $6 \cdot 14$ & SD \\
$2-\mathrm{OH}-12: 0$ & $1 \cdot 00-3.90$ & $2 \cdot 64$ & $1 \cdot 27$ \\
$3-\mathrm{OH}-12: 0$ & $0 \cdot 12-0.45$ & $0 \cdot 34$ & $0 \cdot 61$ \\
$14: 0$ & $0 \cdot 28-0.85$ & 0.59 & $0 \cdot 09$ \\
$16: 1$ & $18 \cdot 76-44.53$ & 40.53 & $0 \cdot 19$ \\
$16: 0$ & $23 \cdot 18-65 \cdot 91$ & 29.01 & 6.98 \\
$\Delta 17: 0$ & $0 \cdot 00-0 \cdot 18$ & 0.06 & 11.67 \\
$18: 1$ & $8 \cdot 47-20 \cdot 10$ & 15.98 & 0.06 \\
& & & 2.96
\end{tabular}

\begin{tabular}{|c|c|c|}
\hline \multicolumn{3}{|c|}{ pv. syringae $(n=4)$} \\
\hline Range & Mean & SD \\
\hline $6 \cdot 29-8 \cdot 72$ & $7 \cdot 55$ & 1.06 \\
\hline $3 \cdot 16-3 \cdot 90$ & $3 \cdot 58$ & 0.37 \\
\hline $0.42-0.55$ & 0.47 & 0.06 \\
\hline $0.35-0.93$ & 0.66 & 0.28 \\
\hline $22 \cdot 12-32 \cdot 25$ & $25 \cdot 86$ & 4.59 \\
\hline $21 \cdot 04-32 \cdot 10$ & $26 \cdot 38$ & 4.66 \\
\hline $2 \cdot 98-20 \cdot 57$ & $12 \cdot 10$ & $9 \cdot 47$ \\
\hline $11 \cdot 02-21 \cdot 34$ & $16 \cdot 38$ & $5 \cdot 16$ \\
\hline
\end{tabular}

Fatty acid analysis. The primary fatty acids found in $P$. s. tomato strains (in order of decreasing percentage composition) were 9-hexadecenoic acid (16:1), hexadecanoic acid (16:0), 9octadecenoic acid (18:1), dodecanoic acid (12:0), 2-hydroxydodecanoic (2-OH-12:0), tetradecanoic acid (14:0) and 3-hydroxydodecanoic acid (3-OH-12:0) (Table 4). The $P$. $s$. syringae strains examined had all of these fatty acids and 9,10-methylenehexadecanoic acid $(\Delta 17: 0)$ as an additional major component. With several exceptions, the variability among strains was relatively small, especially for the $P$. s. tomato strains. The only unusual $P$. s. tomato strain was NCPPB 880, which had the highest percentage of hexadecanoic acid and the lowest percentages of all other major fatty acids. The other unusual strains were B76 and B78, the two $P$. s. syringae pathogenic on tomato, which had high percentages of 9,10-methylenehexadecanoic acid $(19.97 \%$ and $20.57 \%)$ when compared with the other two $P$. s. syringae strains tested $(2.98 \%$ and $4.86 \%)$. It is not clear whether this is a characteristic of $P . s$. syringae tomato strains or is due to insufficient sample size.

Two ratios of fatty acid content may be useful in differentiating $P$. s. tomato from $P$. s. syringae. For the $P$. s. tomato strains the ratios of $12: 0 / 16: 1$ and $\Delta 17: 0 / 16: 0$ were $15 \cdot 19 \pm 1.95$ and $0.20 \pm 0.25$, respectively, whereas for the $P$. s. syringae strains these ratios were $29.46 \pm 2.53$ and $46.91 \pm 36.71$. In both cases the distinguishing ratios were widely different. The standard deviations were small except for the $P$. s. syringae $\Delta 17: 0 / 16: 0$ ratio, where the high $\Delta 17: 0$ content of the two strains pathogenic on tomato caused a large variation in this value.

\section{Plasmid profile}

The $P$. s. tomato strains contained a variety of different plasmids (Fig. $1 a$, Table 5) and, except for JL1120, multiple preparations gave reproducible profiles. The greater diversity of plasmids found here precluded using the plasmid designations of Bender \& Cooksey (1986), and an alternative classification scheme was devised based on both plasmid size and DNA hybridization (Table 5, Fig. $1 b, c$ ). Plasmids were given a letter designation, with numbers to indicate their increasing distance from the origin (decreasing size). The A-type plasmids were generally the largest, with the G-type being the smallest; not all plasmids of a single type were identical. The A-type plasmids were those that hybridized strongly to the plasmid from strain B118 (pB118-A2) (Fig. 1b). The A-type plasmid in NCPPB 2424 was atypical because of its small size. The plasmid from NCPPB 880 was placed in a separate category because, even though it hybridized weakly to pB118-A2, these two plasmids had no identical EcoRI digestion fragments (data not shown). The other bands that pB118-A2 hybridized to were apparently alternative forms of the A-type plasmids, because they appeared only after storage of the plasmid preparations and they hybridized to plasmid probes (Fig. 1b) but not to DNA from strain 10862 (data not shown). Plasmid pB191-A3 gave a pattern of hybridization identical to 


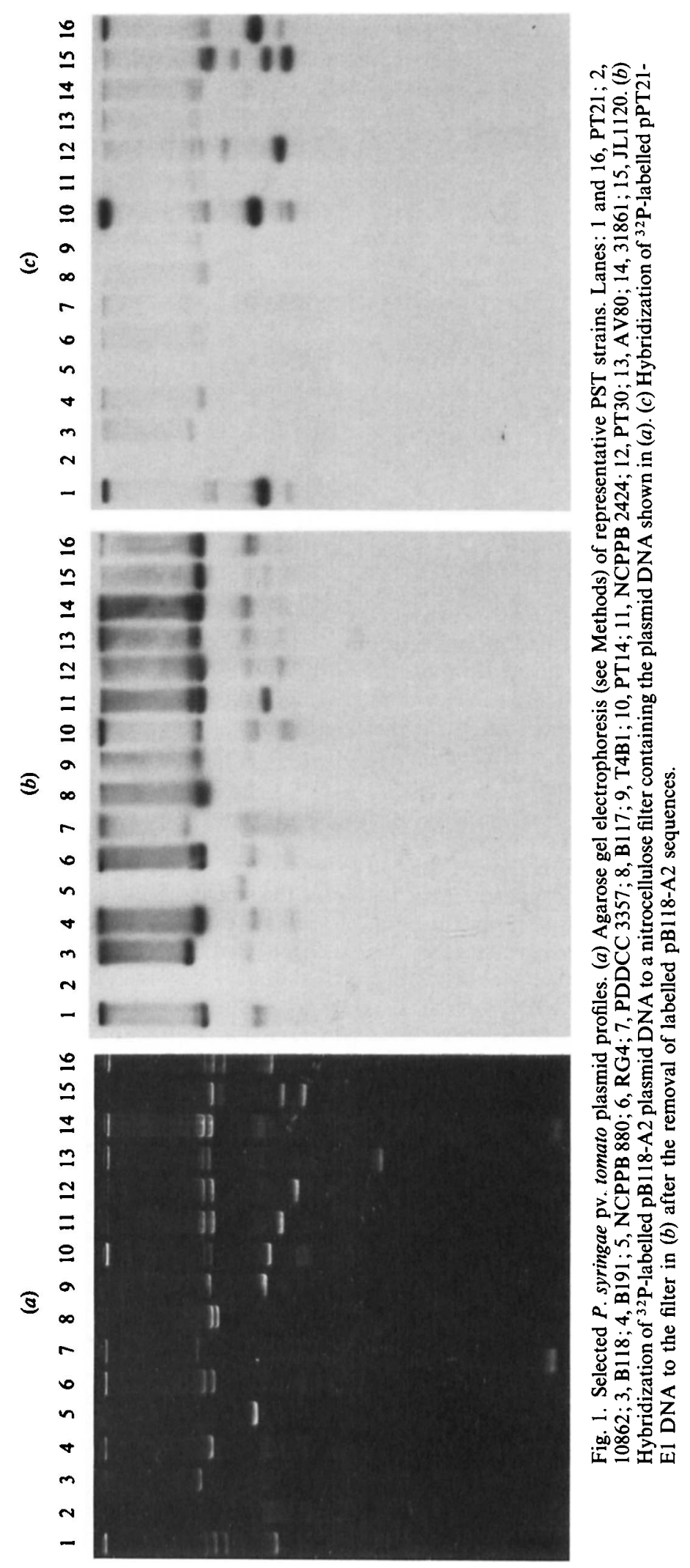


Table 5. Classification of $P$. syringae pv. tomato plasmids

Strains are listed in the same order that they appear in Fig. 1. Strains given in parentheses were identical to the representative strain. Plasmids were grouped according to both size and homology. Generally, Atype plasmids are the largest (with A1 larger than A5), and G-type plasmids the smallest. Type A5 is anomalous, since it hybridized to other A-type plasmids but is smaller than type E1. Presence of plasmid type $=+$. The \pm for JL1120 indicates that early preparations had a A2-type plasmid, but later preparations made for Fig. 1 lacked this plasmid.

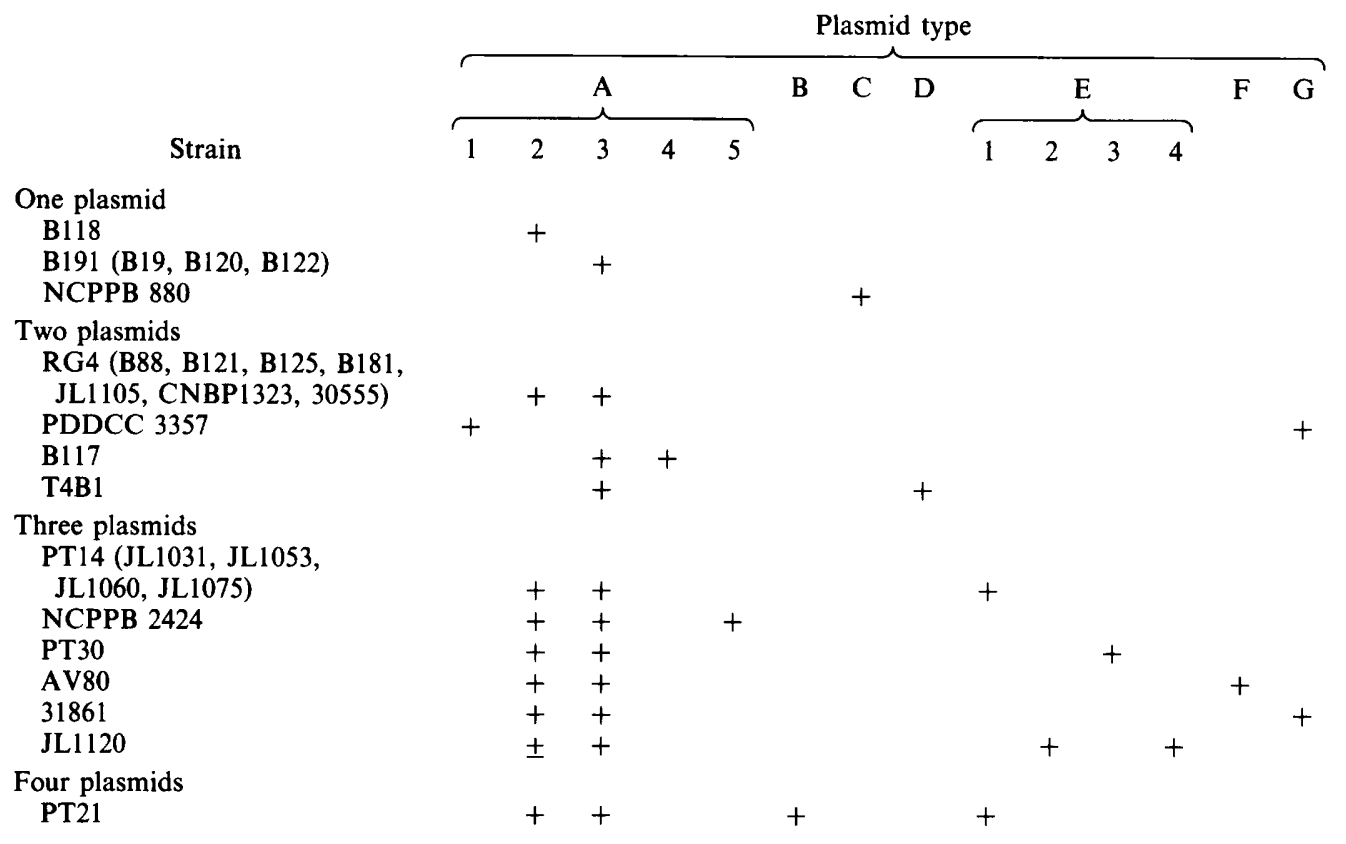

that from $\mathrm{pB} 118-\mathrm{A} 2$, and an $E c o$ RI restriction digest showed that these two plasmids shared 15 of 17 fragments (data not shown). Hybridization of the smallest plasmid from strain PT21 was used to define the E-type plasmids (Fig. 1c). These results showed that the plasmids from T4B1 and NCPPB 2424 were unrelated to the E-type plasmids, even though they were similar in size. The apparent homology between pPT21-E1 and the A-type plasmids was an artifact of the incomplete removal of the ${ }^{32} \mathrm{P}$-labelled $\mathrm{pB} 118-\mathrm{A} 2 \mathrm{DNA}$ before the filter was reused for hybridization with pPT21-E1. The last plasmid used as a probe was pPT21-B, which hybridized only to itself (data not shown). There were a number of plasmids that did not hybridize with any of the four plasmid probes tested, but their relationships were not investigated.

The plasmids appeared in many combinations, ranging in number from zero to four, with most strains having two or more plasmids. No one plasmid was common to all the $P$. s. tomato strains, but the A2- ands A3-type plasmids occurred singly or together in $93 \%$ of the plasmidcontaining strains (Table 5). There was no obvious association between plasmid profile and strain origin except for the small G-type plasmid, which was found in two of the three strains isolated in the South Pacific. No plasmids were found in strain 10862 despite over-loading samples applied to gels (which made the linear DNA contamination more apparent). The absence of plasmid DNA in strain 10862 was also indicated by the failure of ${ }^{32} \mathrm{P}$-labelled total DNA from this strain to hybridize to plasmids bound to nitrocellulose membranes (data not shown).

The plasmid sizes also spanned a large range, but their superhelical conformation and large size made size determinations based on comparison to known plasmids uncertain. Use of the plasmids from Erwinia stewartii strain SW2 (Coplin et al., 1981) led to underestimating the size of the larger $P$. s. tomato plasmids by approximately $30 \%$. Instead, the sizes of the plasmids from strains B118, B191 and NCPPB 880 were determined to be 94,76 and 41 kilobases, respectively, by adding up the sizes of linear fragments produced by EcoRI digestion (HindIII, EcoRI and 
SalI digests of $\lambda$ DNA were used as size standards). These values are in close agreement with those determined by Bender \& Cooksey (1986). The G-type plasmid migrated faster than the $2 \cdot 7$ kilobase pUC9 plasmid, but its precise size was not determined.

Among the $P$. s. syringae strains, only B76 contained a plasmid. The single plasmid in strain B76 (pB76), which was inconsistently isolated in small quantities, was determined to be approximately 74 kilobases based on the sum of the sizes of its EcoRI digestion fragments. None of the EcoRI fragments of pB76 appeared to match those of the 76 kilobase $P$. s. tomato plasmid pB191-A3, and pB76 did not hybridize to a ${ }^{32}$ P-labelled pB191-A3 DNA probe. The low frequency of plasmid-bearing P. s. syringae strains may be unusual (Currier \& Morgan, 1983).

\section{DISCUSSION}

The strains of $P$. s. tomato selected for this study were generally representative, but there were several deficiencies. Since the older strains available were limited in number and geographical distribution, only $10 \%$ of the strains selected were isolated before $1970 ; 38 \%$ of the strains selected were isolated during the 1970 s, and they represented the greatest geographical diversity within this sample. Most of the strains isolated since 1980 were from the USA and Canada. Regions where P. s. tomato has been reported that were not represented are the Mediterranean, Eastern Europe, India, and the UK (see Bradbury, 1986). I welcome the input of other researchers who have strains of $P$. s. tomato that would improve this collection, especially variant strains to further define the limits of this pathovar's diversity.

The collection of $P$. s. tomato and $P$. s. syringae strains was examined for five different phenotypic traits. For pathogenicity tests the number of bacteria in the inoculum, the extent of wounding during inoculation, and the variety of tomato used influenced how virulent the strains appeared to be. In the bacteriophage sensitivity assay culture conditions affected plaque formation and, in conjunction with variation in infectability of the strains, sometimes prevented clear distinctions between positive and negative reactions. [Some of the turbid plaques that I rated positive might have been scored as negative by Cuppels (1983).] Fatty acid content can also be affected by culture conditions and analysis techniques (Jones \& Krieg, 1984), but with reasonable care this test should be reliable for $P$. s. tomato and $P$. s. syringae.

The most atypical $P$. s. tomato strain was 10862 . The oldest strain in the collection, it was nonpathogenic on tomato, grew only on sucrose, and lacked detectable plasmids. Nevertheless, since its fatty acid content was typical of $P$. s. tomato, I believe that strain 10862 should remain a member of this pathovar. No other strain of $P$. s. tomato examined was consistently different from the rest.

All of the phenotypic traits indicated that there was diversity within $P$. s. tomato, but the degree of diversity depended on the trait examined. Little diversity was detected by the tests for pathogenicity, carbohydrate utilization or fatty acid composition. There was greater diversity in bacteriophage sensitivity than in some of the other traits, but this may be because of the lack of specificity exhibited by the phage used. The greatest diversity among the P.s. tomato strains was observed in the plasmid profiles. Classified according to plasmid size and DNA homology there were 14 different plasmid profiles detected among the 28 plasmid-bearing $P$. s. tomato strains. Von Bodman \& Shaw (1987) observed similar variation in the plasmids from six strains of $P$. $s$. coronafaciens. This is much greater variability than that reported for strains of $P$. s. tomato recently isolated in California (Bender \& Cooksey, 1986), and for the $P$. syringae pathovars tabaci and angulata (von Bodman \& Shaw, 1987). The partial conservation of EcoRI restriction fragments and DNA sequences among $P$. s. tomato plasmids appears to be similar to what Lazo \& Gabriel (1987) observed in 10 pathovars of Xanthomonas campestris and von Bodman \& Shaw (1987) found in 4 pathovars of $P$. syringae. The absence of homology between genomic and plasmid DNAs indicated that the variation in plasmid size and number was not due to their acquiring variable sized genomic sequences through insertion and excision as in $P$. syringae pv. phaseolicola (Curiale \& Mills, 1982; Mills et al., 1987).

The assemblage of phenotypic traits clearly differentiates $P$. s. tomato from $P$. s. syringae [and would also distinguish them from $P$. viridiflava (Jones et al., 1984)]. Individually, the tests for 
carbohydrate utilization and fatty acid composition appear to be the most convenient and consistently informative. Without knowledge of a strain's pathogenicity, however, this limited number of tests may not clearly distinguish $P$. s. tomato from pathovars other than $P$. s. syringae. Differentiating closely related pathovars would be aided by better genetic characterization of this complex species. The results of this type of research, which reveal the low genetic diversity within $P$. s. tomato and the clear separation of this pathovar from $P$. s. syringae, are presented in the accompanying paper (Denny et al., 1988).

I thank C. P. Benner for technical assistance, and R. Beaver (Mycotoxin Analysis Research Center, Tifton, Ga., USA) for the fatty acid analysis. This work was supported in part by a Faculty Research Grant from the University of Georgia Research Foundation.

\section{REFERENCES}

Bender, C. L. \& Cooksey, D. A. (1986). Indigenous plasmids in Pseudomonas syringae pv. tomato: conjugative transfer and role in copper resistance. Journal of Bacteriology 165, 534-541.

BENDER, C. L. \& CoOKSEY, D. A. (1987). Molecular cloning of copper resistance genes from Pseudomonas syringae pv. tomato. Journal of Bacteriology 169, 470-474.

Birnboim, H. C. (1983). A rapid alkaline extraction method for the isolation of plasmid DNA. Methods in Enzymology 100, 243-255.

von Bodman, S. B. \& SHaw, P. D. (1987). Conservation of plasmids among plant-pathogenic Pseudomonas syringae isolates of diverse origins. Plasmid 17, 240-247.

Bradbury, J. F. (1986). Guide to Plant Pathogenic Bacteria. Slough, UK: CAB International.

Coplin, D. L., RowaN, R. G., Chisholm, D. A. \& WhITMOYER, R. E. (1981). Characterization of plasmids in Erwinia stewartii. Applied and Environmental Microbiology 42, 599-604.

CUPPELS, D. A. (1983). Isolation and characterization of phages useful for identifying Pseudomonas syringae pv. tomato. Phytopathology 73, 1376-1381.

CUPPELS, D. A. (1986). Generation and characterization of Tn5 insertion mutations in Pseudomonas syringae pv. tomato. Applied and Environmental Microbiology 51, 323-327.

Curiale, M. S. \& Mills, D. (1982). Integration and partial excision of a cryptic plasmid in Pseudomonas syringae pv. phaseolicola. Journal of Bacteriology 152, 797-802.

Currier, T. C. \& Morgan, M. K. (1983). Plasmids of Pseudomonas syringae: no evidence of a role in toxin production or pathogenicity. Canadian Journal of Microbiology 29, 84-89.

Denny, T. P., Gilmour, M. N. \& Selander, R. K. (1988). Genetic diversity and relationships of two pathovars of Pseudomonas syringae. Journal of General Microbiology 134, 1949-1960.

FACKRell, H. B. \& SinHA, R. C. (1983). Serological analysis of Pseudomonas syringae pv. tomato. Phytopathology 73, 178-181.

Getz, S., Stephans, C. T. \& Fulbright, D. W. (1983). Influence of developmental stage on susceptibility of tomato fruit to Pseudomonas syringae pv. tomato. Phytopathology 73, 36-38.

Gitaitis, R. D., Jones, J. B., JAWORKSI, C. A. \& Phatak, S. C. (1985). Incidence and development of Pseudomonas syringae pv. syringae on tomato transplants in Georgia. Plant Disease 69, 32-35.
Gitaitis, R. D., Sasser, M. J., Beaver, R. W., McInnes, T. B. \& Stall, R. E. (1987). Pectolytic xanthomonads in mixed infections with Pseudomonas syringae pv. syringae, $P$. syringae pv. tomato, and Xanthomonas campestris pv. vesicatoria in tomato and pepper transplants. Phytopathology 77, 611615.

GoODE, M. J. \& SASSER, M. (1980). Prevention - the key to controlling bacterial spot and bacterial speck of tomato. Plant Disease 64, 831-834.

JoNES, D. \& KRIEG, N. R. (1984). Serology and chemotaxonomy. In Bergey's Manual of Systematic Bacteriology, vol. 1, pp. 15-18. Edited by N. R. Krieg. Baltimore: Williams \& Wilkins.

Jones, J. B., McCarter, S. M. \& Gitaitis, R. D. (1981). Association of Pseudomonas syringae pv. syringae with a leaf spot disease of tomato transplants in southern Georgia. Phytopathology 71, 1281-1285.

Jones, J. B., DAwE, D. L. \& MCCARTER, S. M. (1983a). Separation of strains of Pseudomonas syringae pv. tomato into serovars by three serological methods. Phytopathology 73, 573-576.

Jones, J. B., Gitaitis, R. D. \& McCarter, S. M. $(1983 b)$. Evaluation of indirect immunofluorescence and ice nucleation activity as rapid tests for identifying foliar diseases of tomato transplants incited by fluorescent pseudomonads. Plant Disease 67, 684-687.

Jones, J. B., Jones, J. P., MCCarter, S. M. \& Stall, R. E. (1984). Pseudomonas viridiflava causal agent of bacterial leaf blight of tomato. Plant Disease 68, 341-342.

Jones, J. B., Gitaitis, R. D. \& McCarter, S. M. (1986). Fluorescence on single-carbon sources for separation of Pseudomonas syringae pv, syringae, $P$. syringae pv. tomato, and $P$. viridiflava on tomato transplants. Plant Disease 70, 151-153.

KIM, S. H. (1979). Dissemination of seed-borne Pseudomonas tomato by transplants. Phytopathology 69, 535.

KING, E. O., WARD, M. K. \& RANeY, D. E. (1954). Two simple media for the demonstration of pyocyanin and fluorescin. Journal of Laboratory and Clinical Methods 44, 301-307.

LAZO, G. R. \& GABRIEL, D. W. (1987). Conservation of plasmid DNA sequences and pathovar identifcation of strains of Xanthomonas campestris. Phytopathology 77, 448-453.

Maniatis, T., Fritsch, E. F. \& Sambrook, J. (1982). Molecular Cloning: a Laboratory Manual. Cold 
Spring Harbor, N.Y.: Cold Spring Harbor Laboratory.

Mills, D., Ehrenshaft, M., Williams, J., Small, C. \& Poplawsky, A. (1987). Plasmid-chromosome recombination in Pseudomonas syringae pv. phaseolicola. In Molecular Strategies for Crop Improvement UCLA Symposia on Molecular and Cellular Biology, New Series, vol. 48. Edited by C. J. Arntzen \& C. Ryan. New York: Alan R. Liss.

Mitchell, R. E., Hale, C. N. \& Shanks, J. C. (1983) Production of different pathogenic symptoms and different toxins by strains of Pseudomonas syringae pv. tomato not distinguishable by gel-immunodiffusion assay. Physiological Plant Pathology 23, 315-322.

Sands, D. C., Schroth, M. N. \& Hildebrand, D. C. (1970). Taxonomy of phytopathogenic pseudomonads. Journal of Bacteriology 101, 9-23.

SCHROTH, M. N., Hildebrand, D. C. \& STARR, M. P. (1981). Phytopathogenic members of the genus Pseudomonas. In The Prokaryotes, pp. 701-718. Edited by M. P. Starr, H. Stolp, H. G. Truper, A. Balows \& H. G. Schlegel. Berlin: SpringerVerlag.
Silhavy, T. J., Berman, M. L. \& Enquist, L. W. (1984). Experiments With Gene Fusions. Cold Spring Harbor, NY: Cold Spring Harbor Laboratory.

SMith, G. E. \& Summers, M. D. (1980). The bidirectional transfer of DNA and RNA to nitrocellulose or diazobenzyloxymethyl-paper. Analytical Biochemistry 109, 123-129.

SMitLeY, D. R. \& MCCARTER, S. M. (1982). Spread of Pseudomonas syringae pv. tomato and role of epiphytic populations and environmental conditions in disease development. Plant Disease 66, 713-717.

WAHL, G. M., STERN, M. \& STARK, G. R. (1979). Efficient transfer of large DNA fragments from agarose gels to diazobenzyloxymethyl-paper and rapid hybridization by using dextran sulfate. Proceedings of the National Academy of Sciences of the United States of America 76, 3683-3687.

Yunis, H., Bashan, Y., OKon, Y. \& Henis, Y. (1980). Weather dependence, yield losses, and control of bacterial speck of tomato caused by Pseudomonas tomato. Plant Disease 64, 937-939. 